\title{
Physicochemical Property-Driven Optimization of Diarylaniline Compounds as Potent HIV-1 Non-Nucleoside Reverse Transcriptase Inhibitors
}

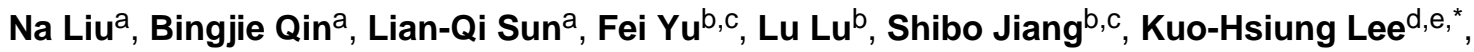 \\ and Lan Xie ${ }^{a,{ }^{*}}$ \\ aBeijing Institute of Pharmacology \& Toxicology, 27 Tai-Ping Road, Beijing, 100850, China \\ bKey Laboratory of Medical Molecular Virology of Ministries of Education and Health, Shanghai \\ Medical College and Institute of Medical Microbiology, Fudan University, Shanghai 200032, China \\ 'Lindsley F. Kimball Research Institute, New York Blood Center, NY 10065, USA \\ dNatural Products Research Laboratories, UNC Eshelman School of Pharmacy, University of \\ North Carolina, Chapel Hill, NC 27599-7568, USA \\ eChinese Medicine Research and Development Center, China Medical University and Hospital, \\ Taichung, Taiwan
}

\begin{abstract}
Using physicochemical property-driven optimization, twelve new diarylaniline compounds (DAANs) (7a-h, 11a-b and 12a-b) were designed and synthesized. Among them, compounds 12a-b not only showed high potency $\left(\mathrm{EC}_{50} 0.96-4.92 \mathrm{nM}\right)$ against both wild-type and drugresistant viral strains with the lowest fold change (FC 0.91 and 5.13), but also displayed acceptable drug-like properties based on aqueous solubility and lipophilicity (LE > 0.3, LLE > 5, LELP < 10). The correlations between potency and physicochemical properties of these DAAN analogues are also described. Compounds 12a-b merit further development as potent clinical trial candidates against AIDS.
\end{abstract}

\section{Keywords}

anti-HIV agents; diarylaniline; NNRTIs; physicochemical property

Non-nucleoside reverse transcriptase inhibitors (NNRTIs) with diverse structures are a key component of antiretroviral therapy (ART) for HIV infection and AIDS, because they exhibit high efficacy and low toxicity, as well as synergistic activity in combination with

\footnotetext{
(C) 2014 Elsevier Ltd. All rights reserved.

*Corresponding author, lanxie4@gmail.com; Tel/Fax: 86-10-66931690 (L. Xie); khlee@ unc.edu; Tel: 919-962-0066; Fax: 919-966-3893.

Publisher's Disclaimer: This is a PDF file of an unedited manuscript that has been accepted for publication. As a service to our customers we are providing this early version of the manuscript. The manuscript will undergo copyediting, typesetting, and review of the resulting proof before it is published in its final citable form. Please note that during the production process errors may be discovered which could affect the content, and all legal disclaimers that apply to the journal pertain.
} 
other anti-HIV drugs. ${ }^{1,2}$ Two new-generation NNRTIs, etravirine (TMC125, 1a) and rilpivirine (TMC278, 1b) (Fig. 1), which were recently approved by the FDA for anti-AIDS therapy, have much better potency and pharmacological profiles than early NNRTIs, such as nevriapine, delavirdine, and efavirenz, and can efficiently inhibit a broad spectrum of drugresistant viral strains. ${ }^{3}$ However, clinical trials revealed novel resistance mutations ${ }^{4}$ conferred against drugs 1a and 1b, which are both diarylpyrimidine (DAPY) compounds, similar to the early NNRTIs. However, these newly produced resistance mutations differ from those affecting the early NNRTIs and from each other, suggesting that a subtle structural difference between the drugs was sufficient to cause the occurrence of distinct HIV mutations. This discovery underscores the necessity for developing new NNRTI drugs with diverse scaffolds in order to provide more choices for AIDS treatment and overcome new resistance mutants. Accordingly, a number of new-generation NNRTI agents with diverse structures have been discovered ${ }^{5}$ and are currently undergoing preclinical and clinical trials.

In our prior studies, several diarylanilines (DAANs) were identified as novel class of HIV-1 non-nucleoside reverse transcriptase inhibitor (NNRTI) agents with low nanomolar anti-HIV potency against wild-type and mutated viral strains ${ }^{6,7}$, both comparable to and better than new-generation NNRTI drugs $\mathbf{1 a}$ and $\mathbf{1 b}$. These DAANs are shown in Figure 1 as leads $\mathbf{2 a}$ and $\mathbf{2 b}$. However, their poor aqueous solubility $(<1 \mu \mathrm{g} / \mathrm{mL})$ resulted in very low absorption in vivo. To improve molecular aqueous solubility, several polar groups ${ }^{8,9}$, including carboxyl, ester, amide, hydroxyl, and $\mathrm{CF}_{3}$, were introduced at the $\mathrm{R}^{1}$ group on the central phenyl ring, a point known to be modifiable for anti-HIV potency, while also associated with molecular physicochemical properties. These efforts led to the discovery of hydroxymethyl-DAAN 2c (Fig. 1) with high potency against wild-type and multi drugresistant viral strains ( $\mathrm{EC}_{50} 0.53 \mathrm{nM}$ and $0.4 \mathrm{nM}$, respectively) and improved aqueous solubility of $3.23 \mu \mathrm{g} / \mathrm{mL}$ at $\mathrm{pH} 7.4$ and $20.9 \mu \mathrm{g} / \mathrm{mL}$ at $\mathrm{pH}$ 2.0. Unfortunately, 2c displayed low oral bioavailability (F\% 6.10) in pharmacokinetics assays in vivo. Herein, we have again modified the DAAN compounds to identify potential drug candidates with balanced potency and a desirable absorption, distribution, metabolism, and excretion (ADME) profile.

To explore the correlations between potency and physicochemical properties associated with ADME profile, we continued to focus on the $\mathrm{R}^{1}$ substituent on the central phenyl ring. In our newly designed series of DAAN analogues (7a-h, 11a-b, 12a-b), $\mathrm{R}^{1}$ was altered to alkylamines or alkoxyethers with different shapes, lengths or volumes. After anti-HIV evaluations, the new active DAAN compounds were further assessed for multiple physicochemical properties, including aqueous solubility and lipophilicity, as estimated by $\log$ P. Apart from aqueous solubility, lipophilicity is another major physicochemical property that contributes to potency, affects compound solubility, determines the passive permeability of small molecules through biological membranes, impacts drug metabolism and pharmacokinetics, and influences adverse effects and compound-related toxicity. Most recently, new lipophicilic parameters, i.e., lipophilic efficiency (LE), lipophilic ligand efficiency (LLE), ${ }^{10}$ and ligand-efficiency-dependent lipophilicity (LELP), ${ }^{11}$ have been proposed and applied in many medicinal chemistry programs ${ }^{12,13,14}$ to efficiently guide lead optimization. Herein, the synthesis, anti-HIV potency, and assessments of multiple 
physicochemical properties of three series of new DAAN compounds (7a-h, 11a-b, 12a-b) are reported. The results will be helpful in guiding our further lead optimization aimed at the discovery of new clinical trial candidates as potent anti-AIDS drugs.

As shown in Scheme 1, target DAAN compounds 7a-h were prepared through a short synthetic route, starting from commercially available 4-hydroxy-3,5-dimethylbenzonitrile (3). The previously synthesized intermediate 5-chloro- $N^{1}$-(4-cyanophenyl)-4methoxycarbonyl-2-nitroaniline (4) ${ }^{8}$ was coupled with 3 in the presence of potassium carbonate in DMF under $120^{\circ} \mathrm{C}$ for $6 \mathrm{~h}$ to afford 2,4-diarylnitrobenzene 5. By using lithium borohydride $\left(\mathrm{LiBH}_{4}\right)$, the ester group on the central phenyl ring in 5 was reduced to a hydroxymethyl group in the key intermediate 6a. Subsequently, 6a was treated with 2,4,6trichloro-[1,3,5]triazine followed by nucleophilic substitution with methylamine, cyclopropanamine, 3-aminopropan-1-ol, or 1-methyl-piperazine to produce the corresponding compounds $\mathbf{6 b}-\mathbf{e}$, respectively, with different alkylamines at the $\mathrm{R}^{1}$ position. Alternatively, 6a was reacted with isopropanol or methanol in the presence of bismuth chloride $\left(\mathrm{BiCl}_{3}\right)$ to afford the corresponding alkoxymethyl-DAAN compounds $6 \mathbf{6}$ and $\mathbf{6 g}$. Furthermore, the hydroxyl group in $\mathbf{6 a}$ was esterified with acetic anhydride to yield compound $\mathbf{6 h}$. Finally, the nitro group on the central ring of $\mathbf{6 a}-\mathbf{h}$ was reduced via catalytic hydrogenation in the presence of Pd-C (10\%) in either EtOAc or anhydrous ethanol to furnish new DAAN compounds 7a-h. The structures of these new DAAN compounds were identified from proton NMR and MS spectra. ${ }^{15}$

Newly synthesized DAAN compounds 7a-h were initially evaluated against wild-type HIV-1 (IIIB) replication in MT-2 cells in parallel with drug $\mathbf{1 b}$. The data are presented in Table 1. As expected, most new DAANs, except 7e with a bulky $N$-methylpiperazinyl group at the $\mathrm{R}^{1}$ position $\left(\mathrm{EC}_{50} 170 \mathrm{nM}\right)$, exhibited low nanomolar potency with $\mathrm{EC}_{50}$ values ranging from 1.06 to $14 \mathrm{nM}$ and high selective index (SI) values of 1,142 to 114,019. The new 7-series compounds were also evaluated against K103N/Y181C mutant-derived, NNRTI-resistant viral strain A17. However, their potencies against the wild-type viral strain were clearly reduced, as demonstrated by $\mathrm{EC}_{50}$ values of greater than 33 to $2,000 \mathrm{nM}$.

Based on previous SAR results, ${ }^{9}$ we then designed and synthesized two pairs of compounds 11a-b and 12a-b with a para-cyanovinyl and para-cyanoethyl $\left(\mathrm{R}^{2}\right)$ group, respectively, on the phenoxy ring (C-ring), as shown in Scheme 2. Similarly to the preparation of $\mathbf{7 g}$ and $\mathbf{7 h}$, methoxymethyl-DAAN 9 and acetoxymethyl-DAAN 10 were synthesized from $N^{1}$-(4cyanophenyl)-5-(4'-cyanovinyl-2',6'-dimethylphenoxy)-4-hydroxymethyl-2-nitroaniline (8). ${ }^{9}$ Subsequently, the nitro group in $\mathbf{9}$ and $\mathbf{1 0}$ was reduced with iron powder in the presence of $\mathrm{NH}_{4} \mathrm{Cl}$ to afford corresponding para-cyanovinyl-DAAN compounds 11a and $\mathbf{1 1 b},{ }^{15}$ respectively, while the nitro group $\left(\mathrm{R}^{1}\right)$ and the conjugated double bond in the cyanovinyl group $\left(\mathrm{R}^{2}\right)$ of $\mathbf{9}$ and $\mathbf{1 0}$ were reduced simultaneously using catalytic hydrogenation with $\mathrm{Pd} / \mathrm{C}$ to produce para-cyanoethyl-DAAN compounds $\mathbf{1 2 a}$ and $\mathbf{1 2 b} .^{15}$ The two pairs of compounds, 11a-b and 12a-b, exhibited high potency against wild-type HIV-1 replication with sub- to low nanomolar $\mathrm{EC}_{50}$ values ranging from 0.83 to $5.74 \mathrm{nM}$, and were as or more potent than $\mathbf{7 g}$ and $\mathbf{7 h}$, regardless of whether $\mathrm{R}^{2}$ was $p$-cyanovinyl or $p$ cyanoethyl. More importantly, compounds 12a-b showed high potency against resistant 
viral strain A17. Specifically, cyanoethyl-DAAN 12a $\left(\mathrm{EC}_{50} 2.95 \mathrm{nM}\right)$ was more potent than cyanovinyl-DAAN 11a $(14.7 \mathrm{nM})$, while both were more potent than cyano-DAAN compound $7 \mathbf{g}(298 \mathrm{nM})$. Similar differences in potency were observed when comparing acetoxymethyl-DAAN compounds $\mathbf{1 2 b}(4.92 \mathrm{nM}), \mathbf{1 1 b}(36.5 \mathrm{nM})$, and $7 \mathbf{h}(374 \mathrm{nM})$. These results clearly demonstrate that the $\mathrm{R}^{2}$ group on the phenoxy ring (C-ring) directly affects molecular potency against wild-type, as well as resistant, viral strains. A cyanoethyl group, which is more flexible due to its linearity, was more favorable than a cyanovinyl or cyano group. Notably, highly potent 12a and 12b had low fold change (FC) between A17 and wild-type IIIB virus with FC values of 0.91 and 5.13, respectively, much lower than that of $\mathbf{1 b}$ (FC 18.4) in the same assay.

Next, several physicochemical properties of newly generated DAANs $\left(\mathrm{EC}_{50}<11 \mathrm{nM}\right)(\mathbf{7 a}-$ d, 7g-h, 11a-b, 12a-b) and drug $\mathbf{1 b}$ were assessed, and the resulting data are summarized in Table 2. Aqueous solubility was measured by HPLC at $\mathrm{pH} 2.0$ and 7.4 to reflect the physiological conditions encountered by these compounds in stomach and plasma, respectively. As expected, alkylamine-DAAN compounds $\mathbf{7 b}, \mathbf{7 c}$, and $\mathbf{7 d}$ displayed greatly improved solubility at both $\mathrm{pH} 2.0(263,285$, and $290 \mu \mathrm{g} / \mathrm{mL}$, respectively) and $\mathrm{pH} 7.4$ (159, 13 , and $236 \mu \mathrm{g} / \mathrm{mL}$, respectively) compared with drug $\mathbf{1 b}(\mathrm{pH} 2.0,74 \mu \mathrm{g} / \mathrm{mL} ; \mathrm{pH} 7.4,0.29$ $\mu \mathrm{g} / \mathrm{mL}$ ). Thus, the introduction of suitable alkylamino groups at the $\mathrm{R}^{1}$ position could greatly improve the molecular aqueous solubility. Active compounds hydroxymethylDAAN 7a $\left(\mathrm{R}^{1}=\mathrm{CH}_{2} \mathrm{OH}\right)$, methoxymethyl-DAANs $7 \mathbf{g}, \mathbf{1 1 a}$, and 12a $\left(\mathrm{R}^{1}=\mathrm{CH}_{2} \mathrm{OMe}\right)$, and acetoxymethyl-DAANs $\mathbf{7 h}, \mathbf{1 1} \mathbf{b}$, and $\mathbf{1 2 b}\left(\mathrm{R}^{1}=\mathrm{CH}_{2} \mathrm{OAc}\right)$ also demonstrated improved aqueous solubility at pH $2.0(1.7-9.10 \mu \mathrm{g} / \mathrm{mL})$, but not at $\mathrm{pH} 7.4(<1 \mu \mathrm{g} / \mathrm{mL})$. For oral drug candidates, better aqueous solubility at $\mathrm{pH} 2.0$ is desirable to enhance absorbability in the stomach. ${ }^{18}$ Meanwhile, we observed that all 10 new active compounds had lower melting points than $\mathbf{1 b}$. This difference might be explained by the assumption that the $\mathrm{R}^{1}$ group on the central phenyl ring might disrupt molecular planarity and crystal packing, ${ }^{19}$ which could also enhance molecular aqueous solubility. To estimate molecular lipophilicity, the $\log \mathrm{P}$ parameters of these active compounds were measured by HPLC at $\mathrm{pH} 7.4 .{ }^{9}$ The experimental $\log \mathrm{P}$ values fell within an acceptable range of 1.80-4.40, which is consistent with the measured aqueous solubilities, and showed the same trend as the clog D values predicted by ACD software. Additionally, topological polar surface area ( $t \mathrm{PSA}$ ) parameters of all active compounds were calculated by ChemDraw Ultra 12.0 and met the criterion ${ }^{20}$ of $<140 \AA^{2}$ for potential oral drug candidates.

To estimate the possible ADME profiles and potential of our drug candidates, we focused next on their lipophilic indices, including lipophilic efficiency (LE), lipophilic ligand efficiency (LLE), and ligand-efficiency-dependent lipophilicity (LELP). Defined as the difference between the negative logarithm of the measured potency $\left(\mathrm{pEC}_{50}\right)$ and $\log \mathrm{P}, \mathrm{LLE}$ quantifies the contribution of lipophilicity to potency, whereas LELP ${ }^{17}$ correlates with ADME properties. Thus, compounds with a low LELP value would most likely have a high chance of passing all ADME and safety criteria, ${ }^{21}$ while compounds with high LELP values (typically > 10) would have a higher propensity to fail because of ADME and safety risks. Accordingly, lipophilic parameters of the new active DAANs were calculated from their experimental $\mathrm{EC}_{50}$ and $\log \mathrm{P}$ values by the formulas cited at the bottom of Table 2 . 
Consequently, compounds 7a, 7b, 7d, 12a, and 12b met acceptable levels for all three ligand lipophilic-efficiency indices (LE $>0.3$, LLE $>5$, LELP $<10$ ), ${ }^{21}$ while the remaining compounds in Table 2 did not, having either LLE values lower than 5 or LELP values higher than 10. Among the five promising compounds, $\mathbf{7 b}$ and $\mathbf{7 d}$ showed higher aqueous solubility at different $\mathrm{pH}$ conditions as well as lower $\log \mathrm{P}$ and LELP values than the other compounds, suggesting better ADME profiles. On the other hand, the 7 series of DAANs were not efficient against resistant viral strain A17. Compounds 12a and 12b did show more balanced potency between the HIV-1 wild-type and resistant viral strains, as well as met acceptable lipophilic criteria, as determined by the LE, LLE and LELP indices. However, the aqueous solubility of both compounds was obviously lower than that of either $\mathbf{7 b}$ or $\mathbf{7 d}$. Thus, to avoid the risk of potential oral absorption, these results suggested that the 12a-b pair requires additional optimization to improve aqueous solubility.

In summary, three series of new DAAN compounds (7a-h, 11a-b, and 12a-b) with interchangeable $\mathrm{R}^{1}$ and $\mathrm{R}^{2}$ modification/optimization were successfully synthesized as part of our ongoing anti-HIV NNRTI program. Our current physicochemical property-driven optimization resulted in the discovery of two promising compounds, $\mathbf{1 2 \mathbf { a }}$ and $\mathbf{1 2 \mathbf { b }}$, with high potency against wild-type and drug-resistant viral strains, low nanomolar $\mathrm{EC}_{50}$ values (0.96-4.92 nM), low fold change resistance (FC 0.91 and 5.13), and acceptable lipophilicity, as demonstrated by meeting acceptable values for all lipophilic parameters (LE > 0.3, LLE > 5 , LELP $<10 ; \log \mathrm{P}<5, t$ PSA $\left.<140 \AA^{2}\right)^{21}$, even though their aqueous solubility needs further improvement. Optimization of the series 7 compounds revealed that (1) the presence of an alkylamine substituent at the $\mathrm{R}^{1}$ position can greatly improve molecular aqueous solubility (see 7b-d) without loss of antiviral potency, (2) a bulky $\mathrm{R}^{1}$ group can result in substantially impaired antiviral activity (see 7e), and (3) introducing an H-bond acceptor or donor at the $\mathrm{R}^{1}$ position (such as $\mathbf{7} \mathbf{a}-\mathbf{b}, \mathbf{7} \mathbf{d}-\mathbf{g}$ ) might regulate the molecular lipophilicity to meet desired drug criteria. Our optimization efforts at the $\mathrm{R}^{2}$ position on the phenoxy ring (C-ring) indicated that a more flexible and longer linear cyanovinyl (11 series) or, preferably, cyanoethyl (12 series) substituent, rather than a cyano group (7 series) is crucial for high potency against both wild-type and double-mutant drug-resistant viral strains (compare 7g-h, 11a-b, and 12a-b). Consequently, a number of compounds from this series are being considered for in vivo pharmacokinetic evaluation, and the results will be reported later.

\section{Acknowledgments}

This investigation was supported by grants 30930106 and 81120108022 from the Natural Science Foundation of China (NSFC) to L. Xie, the National Megaprojects of China for Major Infectious Diseases (2013ZX10001-006) to L. Xie and S. Jiang, and U.S. NIH grant (AI33066) to K. H. Lee. This study was also supported in part by the Taiwan Department of Health, China Medical University Hospital Cancer Research Center of Excellence (DOH100-TD-C-111-005).

\section{References and Notes}

1. Tronchet JM, Seman M. Curr Top Med Chem. 2003; 3:1496. [PubMed: 14529523]

2. Tarby CM. Curr Top Med Chem. 2004; 4:1045. [PubMed: 15193138]

3. Guillemont J, Pasquier E, Palandjian P, Vemier D, Gaurrand S, Lewi PJ, Heeres J, De Jonge MR, Koymans LMH, Daeyaert FFD, Vinkers MH, Arnold E, Das K, Pauwels R, Andries K, De Bethune 
M-P, Bettens E, Hertogs K, Wigerinck P, Timmerman P, Janssen PA. J Med Chem. 2005; 48:2072. [PubMed: 15771449]

4. Bourgeois A, Womack S, Newsom D, Caldwell D. HIV Clinician. 2012; 24:12. [PubMed: 23259177]

5. Rawal RK, Murugesan V, Katti SB. Curr Med Chem. 2012; 19:5364. [PubMed: 22998569]

6. Qin B, Jiang XK, Lu H, Tian XT, Barbault F, Huang L, Qian K, Chen CH, Huang R, Jiang S, Lee KH, Xie L. J Med Chem. 2010; 53:4906. [PubMed: 20527972]

7. Tian XT, Qin B, Wu ZY, Wang XF, Lu H, Morris-Natschke SL, Chen CH, Jiang S, Lee KH, Xie L. J Med Chem. 2010; 53:8287. [PubMed: 21049929]

8. Sun LQ, Qin B, Huang L, Qian K, Chen CH, Lee KH, Xie L. Bioorg Med Chem Lett. 2012; 22:2376. [PubMed: 22406117]

9. Sun LQ, Zhu L, Qian K, Qin B, Huang L, Chen CH, Lee KH, Xie L. J Med Chem. 2012; 55:7219. [PubMed: 22856541]

10. Leeson PD, Springthorpe B. Nat Rev Drug Discovery. 2007; 6:881.

11. Keseru GM, Makara GM. Nat Rev Drug Discovery. 2009; 8:203.

12. Jabeen I, Plehab K, Rinner U, Chibe P, Ecker GF. J Med Chem. 2012; 55:3261. [PubMed: 22452412]

13. Christiansen E, Due-Hansen ME, Urban C, Grundmann M, Schroder R, Hudson BD, Milligan G, Cawthorne MA, Kostenis E, Kassack MU, Ulven T. J Med Chem. 2012; 55:6624. [PubMed: 22724451]

14. Diaz JL, Christmann U, Fernandez A, Luengo M, Bordas M, Enrech R, Carro M, Pascual R, Burgueno J, Merlos M, Bebet-Buchholz J, Ceron-Bertran J, Ramirez J, Reinoso RF, de Henestrosa FAR, Vela JM, Almansa C. J Med Chem. 2013; 56:3656. [PubMed: 23560650]

15. Synthetic procedure for 4-substituted 1,5-diarylbenzene-1,2-diamines (7a-h and 12a-b). A solution of diarylnitrobenzene in $20 \mathrm{~mL}$ of anhydrous EtOAc (for 7a-c, 7e-f) or anhydrous EtOH (for 7d, 7g-h, 12a-b) in the presence of excess Pd/C (5\%) was shaken with hydrogen gas under 50-55 p.s.i. until the hydrogen was no longer absorbed (ca. $4 \mathrm{~h}$ ). The catalyst was filtered from the solution and washed with EtOAc several times. After the solvent was removed under reduced pressure, the residue was purified by flash column chromatography (gradual elution: $\mathrm{MeOH} / \mathrm{CH}_{2} \mathrm{Cl}_{2}, 0-5 \%$ ) with the Combiflash ${ }^{\circledR}$ flash chromatography system (Teledyne ISCO Company, Inc., Lincoln, NE) to obtain pure target compounds $\mathbf{7 a - h}$ and 12a-b. Otherwise, paracyanovinyl-compounds 11a and 11b were obtained from 9 and $\mathbf{1 0}$ by reaction with excess iron powder in the presence of $\mathrm{NH}_{4} \mathrm{Cl}$ at reflux temperature in a mixed solvent of THF/water/MeOH (v/v/v 1:1:1) for $4 \mathrm{~h} .7 \mathbf{a}:$ yield $73 \%$, white solid, mp $230.0-232{ }^{\circ} \mathrm{C} ;{ }^{1} \mathrm{H} \mathrm{NMR}\left(\mathrm{CDCl}_{3}\right) \delta \mathrm{ppm} 2.14$ $\left(6 \mathrm{H}, \mathrm{s}, 2 \times \mathrm{CH}_{3}\right), 4.88\left(2 \mathrm{H}, \mathrm{s}, \mathrm{CH}_{2}\right), 5.51(1 \mathrm{H}, \mathrm{s}, \mathrm{NH}) 5.99(1 \mathrm{H}, \mathrm{s}, \mathrm{ArH}-6), 6.54(2 \mathrm{H}, \mathrm{d}, J=8.4 \mathrm{~Hz}$, ArH-2',6' 6.97 (1H, s, ArH-3), 7.40 (2H, s, ArH-3", 5" $), 7.41\left(2 \mathrm{H}, \mathrm{d}, J=8.4 \mathrm{~Hz}, \mathrm{ArH}-3^{\prime}, 5^{\prime}\right)$; MS $\mathrm{m} / z(\%) 385.2(\mathrm{M}+1,100)$. 7b: white solid, mp 201-203 ${ }^{\circ} \mathrm{C} ;{ }^{1} \mathrm{H} \mathrm{NMR}\left(\mathrm{CDCl}_{3}\right) \delta \mathrm{ppm} 2.13(6 \mathrm{H}$, $\left.\mathrm{s}, 2 \times \mathrm{CH}_{3}\right), 2.56\left(3 \mathrm{H}, \mathrm{s}, \mathrm{NCH}_{3}\right), 3.58\left(2 \mathrm{H}, \mathrm{s}, \mathrm{NH}_{2}\right), 3.95\left(2 \mathrm{H}, \mathrm{s}, \mathrm{ArCH}_{2}\right), 5.51(1 \mathrm{H}, \mathrm{s}, \mathrm{NH}), 5.96$ (1H, s, ArH-6), 6.53 (2H, d, $J=8.4$ Hz, ArH-2',6'), 6.93 (1H, s, ArH-3), 7.38 (2H, s, ArH-3", $\left.5^{\prime \prime}\right)$, $7.39\left(2 \mathrm{H}, \mathrm{d}, J=8.4 \mathrm{~Hz}, \mathrm{ArH}-3^{\prime}, 5^{\prime}\right)$; MS $m / z(\%) 398.1(\mathrm{M}+1,1), 358(\mathrm{M}-30,100)$. 7c: yield $83 \%$, white solid, mp $72.0-73.3{ }^{\circ} \mathrm{C} ;{ }^{1} \mathrm{H}$ NMR $\left(\mathrm{CDCl}_{3}\right) \delta \mathrm{ppm} 0.49\left(4 \mathrm{H}, \mathrm{m}, \mathrm{CH}_{2} \mathrm{CH}_{2}\right), 2.14(6 \mathrm{H}, \mathrm{s}$, $\left.2 \times \mathrm{CH}_{3}\right), 2.24(3 \mathrm{H}, \mathrm{m}, \mathrm{CH}), 3.53\left(2 \mathrm{H}, \mathrm{s}, \mathrm{NH}_{2}\right), 4.00\left(2 \mathrm{H}, \mathrm{s}, \mathrm{ArCH}_{2}\right), 5.48(1 \mathrm{H}, \mathrm{s}, \mathrm{NH}), 5.96(1 \mathrm{H}$, s, ArH-6), 6.53 (2H, d, $\left.J=8.8 \mathrm{~Hz}, \mathrm{ArH}-2^{\prime}, 6^{\prime}\right), 6.93(1 \mathrm{H}, \mathrm{s}, \mathrm{ArH}-3), 7.38\left(2 \mathrm{H}, \mathrm{s}, \mathrm{ArH}-3^{\prime \prime}, 5^{\prime \prime}\right), 7.39$ $\left(2 \mathrm{H}, \mathrm{d}, J=8.8 \mathrm{~Hz}, \mathrm{ArH}-3^{\prime}, 5^{\prime}\right)$; MS $m / z(\%) 434.2(\mathrm{M}+1,3), 367.2(\mathrm{M}-56,100) .7 \mathrm{~d}$ : yield $38 \%$, white solid, mp 76.0-78.0 ${ }^{\circ} \mathrm{C} ;{ }^{1} \mathrm{H}$ NMR $\left(\mathrm{CDCl}_{3}\right) \delta \mathrm{ppm} 1.79\left(2 \mathrm{H}, \mathrm{f}, J=5.6 \mathrm{~Hz}, \mathrm{CH}_{2}\right), 2.13(6 \mathrm{H}, \mathrm{s}$, $\left.2 \times \mathrm{CH}_{3}\right), 3.01\left(2 \mathrm{H}, \mathrm{t}, J=5.6 \mathrm{~Hz}, \mathrm{NCH}_{2}\right), 3.87\left(2 \mathrm{H}, \mathrm{t}, J=5.6 \mathrm{~Hz}, \mathrm{CH}_{2} \mathrm{O}\right), 3.95\left(2 \mathrm{H}, \mathrm{s}, \mathrm{ArCH}_{2}\right)$, $5.51(1 \mathrm{H}, \mathrm{s}, \mathrm{NH}), 5.96(1 \mathrm{H}, \mathrm{s}, \mathrm{ArH}-6), 6.54\left(2 \mathrm{H}, \mathrm{d}, J=8.8 \mathrm{~Hz}, \mathrm{ArH}-2^{\prime}, 6^{\prime}\right), 6.86(1 \mathrm{H}, \mathrm{s}, \mathrm{ArH}-3)$, $7.39\left(2 \mathrm{H}, \mathrm{s}, \mathrm{ArH}-3^{\prime \prime}, 5^{\prime \prime}\right), 7.41\left(2 \mathrm{H}, \mathrm{d}, J=8.8 \mathrm{~Hz}, \mathrm{ArH}-3^{\prime}, 5^{\prime}\right)$; MS $m / z(\%) 442.6(\mathrm{M}+1,20), 367.2$ (M - 74, 100). 7e: yield 40\%, white solid, $\mathrm{mp} 210.2-212.0{ }^{\circ} \mathrm{C} ;{ }^{1} \mathrm{H} \mathrm{NMR}\left(\mathrm{CDCl}_{3}\right) \delta \mathrm{ppm} 2.09(3 \mathrm{H}$, $\left.\mathrm{s}, \mathrm{CH}_{3}\right), 2.08\left(3 \mathrm{H}, \mathrm{s}, \mathrm{CH}_{3}\right), 2.12\left(6 \mathrm{H}, \mathrm{s}, 2 \times \mathrm{CH}_{3}\right), 2.78\left(4 \mathrm{H}, \mathrm{t}, J=4.8 \mathrm{~Hz}, \mathrm{CH}_{2} \mathrm{CH}_{2}\right), 3.05(4 \mathrm{H}, \mathrm{s}$, $\left.J=4.8 \mathrm{~Hz}, \mathrm{CH}_{2} \mathrm{CH}_{2}\right), 3.72\left(2 \mathrm{H}, \mathrm{s}, \mathrm{ArCH}_{2}\right), 5.87(1 \mathrm{H}, \mathrm{s}, \mathrm{NH}), 6.01(1 \mathrm{H}, \mathrm{s}, \mathrm{ArH}-3), 6.60(2 \mathrm{H}, \mathrm{d}, J$ $\left.=8.4 \mathrm{~Hz}, \mathrm{ArH}-2^{\prime}, 6^{\prime}\right), 7.44(2 \mathrm{H}, \mathrm{d}, J=8.4 \mathrm{~Hz}), 7.69\left(2 \mathrm{H}, \mathrm{s}, \mathrm{ArH}-3^{\prime \prime}, 5^{\prime \prime}\right), 8.62(1 \mathrm{H}, \mathrm{s}, \mathrm{ArH}-6)$; MS $\mathrm{m} / \mathrm{z}(\%) 467.6(\mathrm{M}+1,31), 367.3(\mathrm{M}-99,100) .7 f$ : yield 33\%, white solid, mp 140.9-142.9 ${ }^{\circ} \mathrm{C} ;{ }^{1} \mathrm{H} \mathrm{NMR}\left(\mathrm{CDCl}_{3}\right) \delta \mathrm{ppm} 1.28\left(6 \mathrm{H}, \mathrm{d}, J=6.4 \mathrm{~Hz}, 2 \times \mathrm{CH}_{3}\right), 2.14\left(6 \mathrm{H}, \mathrm{s}, 2 \times \mathrm{CH}_{3}\right), 3.81(1 \mathrm{H}$, q, $J=6.4 \mathrm{~Hz}, \mathrm{CH}), 4,69\left(2 \mathrm{H}, \mathrm{s}, \mathrm{ArCH}_{2}\right), 5.53(1 \mathrm{H}, \mathrm{s}, \mathrm{NH}), 5.96(1 \mathrm{H}, \mathrm{s}, \operatorname{ArH}-6), 6.53(2 \mathrm{H}, \mathrm{d}, J=$ 
8.4 Hz, ArH-2',6'), 7.04 (1H, s, ArH-3), 7.38 (2H, s, ArH-3" ,5" ), 7.40 (2H, d, J = 8.4 Hz, ArH-3', $\left.5^{\prime}\right)$; MS $m / z(\%) 427.4(\mathrm{M}+1,100) .7 \mathrm{~g}$ : yield $33 \%$, white solid, $\mathrm{mp} 140.9-142.9{ }^{\circ} \mathrm{C} ;{ }^{1} \mathrm{H} \mathrm{NMR}$ $\left(\mathrm{CDCl}_{3}\right) \delta \mathrm{ppm} 1.28\left(6 \mathrm{H}, \mathrm{d}, J=6.4 \mathrm{~Hz}, 2 \times \mathrm{CH}_{3}\right), 2.14\left(6 \mathrm{H}, \mathrm{s}, 2 \times \mathrm{CH}_{3}\right), 3.81(1 \mathrm{H}, \mathrm{q}, J=6.4 \mathrm{~Hz}$, $\mathrm{CH}), 4,69\left(2 \mathrm{H}, \mathrm{s}, \mathrm{ArCH}_{2}\right), 5.53(1 \mathrm{H}, \mathrm{s}, \mathrm{NH}), 5.96(1 \mathrm{H}, \mathrm{s}, \mathrm{ArH}-6), 6.53\left(2 \mathrm{H}, \mathrm{d}, J=8.4 \mathrm{~Hz}, \mathrm{ArH}-2^{\prime}\right.$, $\left.6^{\prime}\right), 7.04(1 \mathrm{H}, \mathrm{s}, \mathrm{ArH}-3), 7.38\left(2 \mathrm{H}, \mathrm{s}, \mathrm{ArH}-3^{\prime \prime}, 5^{\prime \prime}\right), 7.40\left(2 \mathrm{H}, \mathrm{d}, J=8.4 \mathrm{~Hz}, \mathrm{ArH}-3^{\prime}, 5^{\prime}\right)$; MS m/z (\%) $427.4(\mathrm{M}+1,100)$. 7h: yield $34 \%$, white solid, mp 161.0-162.8 ${ }^{\circ} \mathrm{C} ;{ }^{1} \mathrm{H}$ NMR $\left(\mathrm{CDCl}_{3}\right) \delta \mathrm{ppm}$ $2.14\left(9 \mathrm{H}, \mathrm{s}, 2 \times \mathrm{CH}_{3}, \mathrm{COCH}_{3}\right), 3.55\left(2 \mathrm{H}, \mathrm{s}, \mathrm{NH}_{2}\right), 5.29\left(2 \mathrm{H}, \mathrm{s}, \mathrm{ArCH}_{2}\right), 5.52(1 \mathrm{H}, \mathrm{s}, \mathrm{NH}), 6.00$ (1H, s, ArH-6), 6.56 (2H, d, J = 8.4 Hz, ArH-2',6'), 6.94 (1H, s, ArH-3), 7.39 (2H, s, ArH-3", 5"), 7.42 (2H, d, $\left.J=8.4 \mathrm{~Hz}, \mathrm{ArH}-3^{\prime}, 5^{\prime}\right)$; MS m/z (\%) 427.5 (M + 1, 62), 367 (M - 99, 100). 11a: 50\% yield, white solid, mp $170.5-172.0{ }^{\circ} \mathrm{C} ;{ }^{1} \mathrm{H} \mathrm{NMR}\left(\mathrm{CDCl}_{3}\right) \delta \mathrm{ppm} 2.13\left(6 \mathrm{H}, \mathrm{s}, 2 \times \mathrm{CH}_{3}\right), 3.54(5 \mathrm{H}$, $\left.\mathrm{s}, \mathrm{OCH}_{3}, \mathrm{NH}_{2}\right), 4.67\left(2 \mathrm{H}, \mathrm{s}, \mathrm{CH}_{2} \mathrm{O}\right), 5.51(1 \mathrm{H}, \mathrm{s}, \mathrm{NH}), 5.79(1 \mathrm{H}, \mathrm{d}, J=16.4 \mathrm{~Hz},=\mathrm{CH}), 6.03(1 \mathrm{H}$, s, ArH-6), 6.55 (2H, d, J = 8.8 Hz, ArH-2',6'), 6.99 (1H, s, ArH-3), 7.17 (2H, s, ArH-3", 5"), 7.31 $(2 \mathrm{H}, \mathrm{d}, J=16.4 \mathrm{~Hz}, \mathrm{CH}=), 7.40\left(2 \mathrm{H}, \mathrm{d}, J=8.8 \mathrm{~Hz}, \mathrm{ArH}-3^{\prime}, 5^{\prime}\right)$; $\mathrm{MS} m / z(\%) 425.3(\mathrm{M}+1,100)$. 11b: 35\% yield, white solid, mp 194.1-195.9 ${ }^{\circ} \mathrm{C} ;{ }^{1} \mathrm{H}$ NMR $\left(\mathrm{CDCl}_{3}\right) \delta \mathrm{ppm} 2.14\left(6 \mathrm{H}, \mathrm{s}, 2 \times \mathrm{CH}_{3}\right)$, $2.15\left(3 \mathrm{H}, \mathrm{s}, \mathrm{CH}_{3} \mathrm{CO}\right), 3.53\left(2 \mathrm{H}, \mathrm{s}, \mathrm{NH}_{2}\right), 5.30\left(2 \mathrm{H}, \mathrm{s}, \mathrm{ArCH}_{2} \mathrm{O}\right), 5.51(1 \mathrm{H}, \mathrm{s}, \mathrm{NH}), 5.78(1 \mathrm{H}, \mathrm{d}, J=$ $16.8 \mathrm{~Hz},=\mathrm{CH}), 6.05(1 \mathrm{H}, \mathrm{s}, \mathrm{ArH}-6), 6.55\left(2 \mathrm{H}, \mathrm{d}, J=8.8 \mathrm{~Hz}, \mathrm{ArH}-2^{\prime}, 6^{\prime}\right), 6.93(1 \mathrm{H}, \mathrm{s}, \mathrm{ArH}-3), 7.17$ $\left(2 \mathrm{H}, \mathrm{s}, \mathrm{ArH}-3^{\prime \prime}, 5^{\prime \prime}\right), 7.30(1 \mathrm{H}, \mathrm{d}, J=16.8 \mathrm{~Hz}, \mathrm{CH}=), 7.40(2 \mathrm{H}, \mathrm{d}, J=8.8 \mathrm{~Hz}, \mathrm{ArH}-3) ; \mathrm{MS} m / z(\%)$ $393.2(\mathrm{M}-59,100), 453.3(\mathrm{M}+1,97.2)$. 12a: $79 \%$ yield, white solid, mp $103.6-104.8{ }^{\circ} \mathrm{C} ;{ }^{1} \mathrm{H}$ NMR $\left(\mathrm{CDCl}_{3}\right) \delta \mathrm{ppm} 2.09\left(6 \mathrm{H}, \mathrm{s}, 2 \times \mathrm{CH}_{3}\right), 2.61\left(2 \mathrm{H}, \mathrm{t}, J=7.2 \mathrm{~Hz}, \mathrm{CH}_{2} \mathrm{CN}\right), 2.87(2 \mathrm{H}, \mathrm{t}, J=7.2$ $\left.\mathrm{Hz}, \mathrm{ArCH}_{2}\right), 3.52\left(3 \mathrm{H}, \mathrm{s}, \mathrm{OCH}_{3}\right), 4.67\left(2 \mathrm{H}, \mathrm{s}, \mathrm{CH}_{2} \mathrm{O}\right), 5.56(1 \mathrm{H}, \mathrm{s}, \mathrm{NH}), 6.03(1 \mathrm{H}, \mathrm{s}, \mathrm{ArH}-6), 6.55$ $\left(2 \mathrm{H}, \mathrm{d}, J=8.8 \mathrm{~Hz}, \mathrm{ArH}-2^{\prime}, 6^{\prime}\right), 6.92\left(2 \mathrm{H}, \mathrm{s}, \mathrm{ArH}-3^{\prime \prime}, 5^{\prime \prime}\right), 6.99(1 \mathrm{H}, \mathrm{s}, \mathrm{ArH}-3), 7.39$ (2H, d, $J=8.8$ $\left.\mathrm{Hz}, \mathrm{ArH}-3^{\prime}, 5^{\prime}\right)$; MS m/z (\%) $427.3(\mathrm{M}+1,100)$. 12b: $40 \%$ yield, white solid, mp 164.1-165.7 ${ }^{\circ} \mathrm{C} ;{ }^{1} \mathrm{H}$ NMR (DMSO-d 6$) \delta \mathrm{ppm} 2.04\left(6 \mathrm{H}, \mathrm{s}, 2 \times \mathrm{CH}_{3}\right), 2.09\left(3 \mathrm{H}, \mathrm{s}, \mathrm{COCH}_{3}\right), 2.78(4 \mathrm{H}, \mathrm{s}, 2 \times$ $\left.\mathrm{CH}_{2}\right), 4.58\left(2 \mathrm{H}, \mathrm{s}, \mathrm{NH}_{2}\right), 5.19\left(2 \mathrm{H}, \mathrm{s}, \mathrm{CH}_{2} \mathrm{O}\right), 5.90(1 \mathrm{H}, \mathrm{s}, \mathrm{NH}), 6.54\left(2 \mathrm{H}, \mathrm{d}, J=8.8 \mathrm{~Hz}, \mathrm{ArH}-2^{\prime}\right.$, $\left.6^{\prime}\right), 6.87(1 \mathrm{H}, \mathrm{s}, \mathrm{ArH}-6), 7.04\left(2 \mathrm{H}, \mathrm{s}, \mathrm{ArH}-3^{\prime \prime} 5^{\prime \prime}\right), 7.45\left(2 \mathrm{H}, \mathrm{d}, J=8.8 \mathrm{~Hz}, \mathrm{ArH}-3^{\prime}, 5^{\prime}\right), 8.08(1 \mathrm{H}, \mathrm{s}$, ArH-3); MS m/z (\%) 395.2 (M - 59, 100), 455.3 (M + 1, 17).

16. Jabeen I, Pleban K, Rinner U, Chiba P, Ecker GF. J Med Chem. 2012; 55:3261. [PubMed: 22452412]

17. Keserü GM, Makara GM. Nat Rev Drug Discovery. 2009; 8:203.

18. Ramurthy S, Subramanian S, Aikawa M, Amiri P, Costales A, Dove J, Fong S, Jansen JM, Levine B, Ma S, McBride CM, Michaelian J, Pick T, Poon DJ, Girish S, Shafer CM, Stuart D, Sung L, Renhowe PA. J Med Chem. 2008; 51:7049. [PubMed: 18942827]

19. Ishikawa M, Hashimoto Y. J Med Chem. 2011; 54:1539. [PubMed: 21344906]

20. Veber DF, Johnson SR, Cheng HY, Smith BR, Ward KW, Kopple KD. J Med Chem. 2002; 45:2615. [PubMed: 12036371]

21. Tarcsay A, Nyiri K, Keseru GM. J Med Chem. 2012; 55:1252. [PubMed: 22229549] 


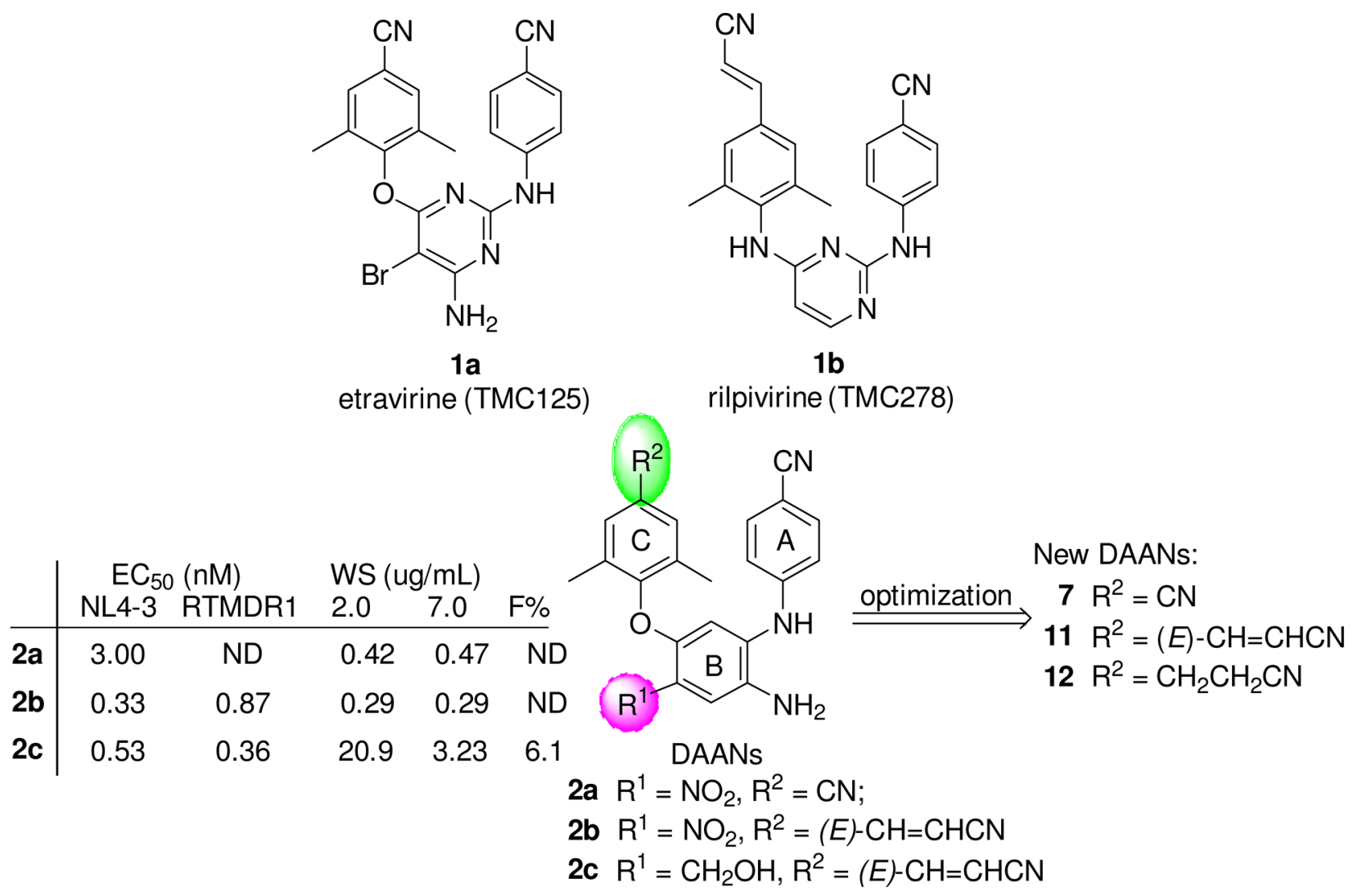

Figure 1.

Next-generation NNRTI drugs, diarylaniline leads (DAANs), and new DAAN analogues 
<smiles>COC(=O)c1cc(Cl)c([N+](=O)[O-])c(Nc2ccc(C#N)cc2)c1</smiles><smiles>CC(=O)c1cc([N+](=O)[O-])c(Nc2ccc(C#N)cc2)cc1Oc1c(C)cc(C#N)cc1C</smiles><smiles>Cc1cc(C#N)cc(C)c1Oc1cc(Nc2ccc(C#N)cc2)c([N+](=O)[O-])cc1CO</smiles><smiles>C=CC(C)(C)C(C)(C)CC</smiles><smiles>[R]Cc1cc(Nc2ccc(C#N)cc2)c([N+](=O)[O-])cc1Oc1c(C)cc(C#N)cc1C</smiles>

6b-e, $X=N$ $6 f-h, X=0$<smiles>[R7]Cc1cc(N)c(Nc2ccc(C#N)cc2)cc1Oc1c(C)cc(C#N)cc1C</smiles>

Scheme 1.

i) $\mathrm{K}_{2} \mathrm{CO}_{3} / \mathrm{DMF}, 120^{\circ} \mathrm{C}, 6 \mathrm{~h}$; ii) $\mathrm{LiBH}_{4}, \mathrm{THF} / \mathrm{MeOH}, 0^{\circ} \mathrm{C}, 7 \mathrm{~h}$; iii) 2,4,6-trichloro$[1,3,5]$ triazine, $\mathrm{DMF} / \mathrm{CH}_{2} \mathrm{Cl}_{2}$, rt, $4 \mathrm{~h}$; iv) amine, THF, $0{ }^{\circ} \mathrm{C}, 0.5 \mathrm{~h}$; v) $\mathrm{ROH} / \mathrm{BiCl}_{3}$, $\mathrm{CH}_{2} \mathrm{Cl}_{2} / \mathrm{CCl}_{4}$, rt, $4 \mathrm{~h}$; (vi) $\mathrm{Ac}_{2} \mathrm{O}, 100{ }^{\circ} \mathrm{C}$, Microwave, 5 min; vii) $\mathrm{H}_{2} / \mathrm{Pd}-\mathrm{C}$ in EtOAc or $\mathrm{EtOH}$. 


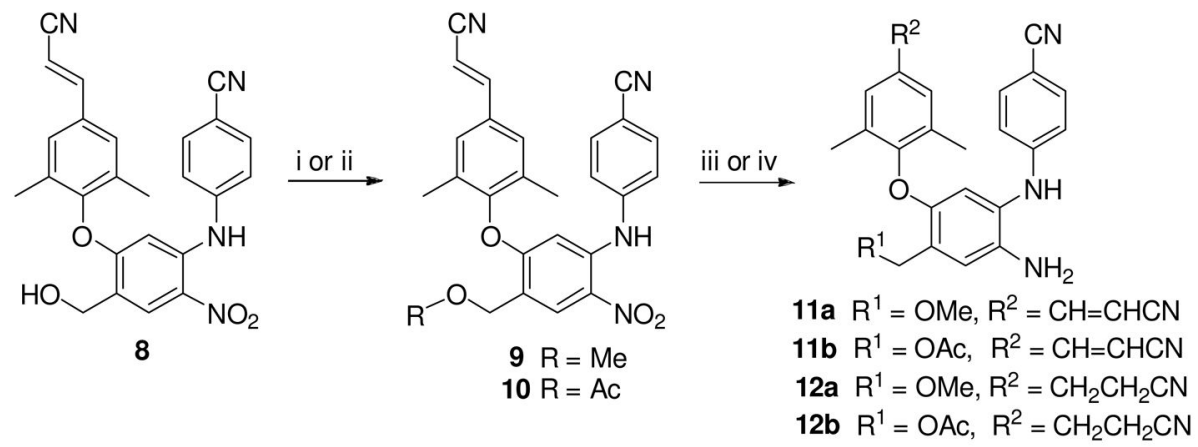

Scheme 2.

i) $\mathrm{ROH} / \mathrm{BiCl}_{3}, \mathrm{CH}_{2} \mathrm{Cl}_{2} / \mathrm{CCl}_{4}$, r.t. 4 h; ii) $\mathrm{Ac}_{2} \mathrm{O}, 100{ }^{\circ} \mathrm{C}$, Microwave, 5 min; iii) $\mathrm{Fe}, \mathrm{NH}_{4} \mathrm{Cl}$, $\mathrm{THF} / \mathrm{MeOH} / \mathrm{H}_{2} \mathrm{O}$, reflux, $3 \mathrm{~h}$; iv) $\mathrm{H}_{2} / \mathrm{Pd}-\mathrm{C}$ in EtOH. 


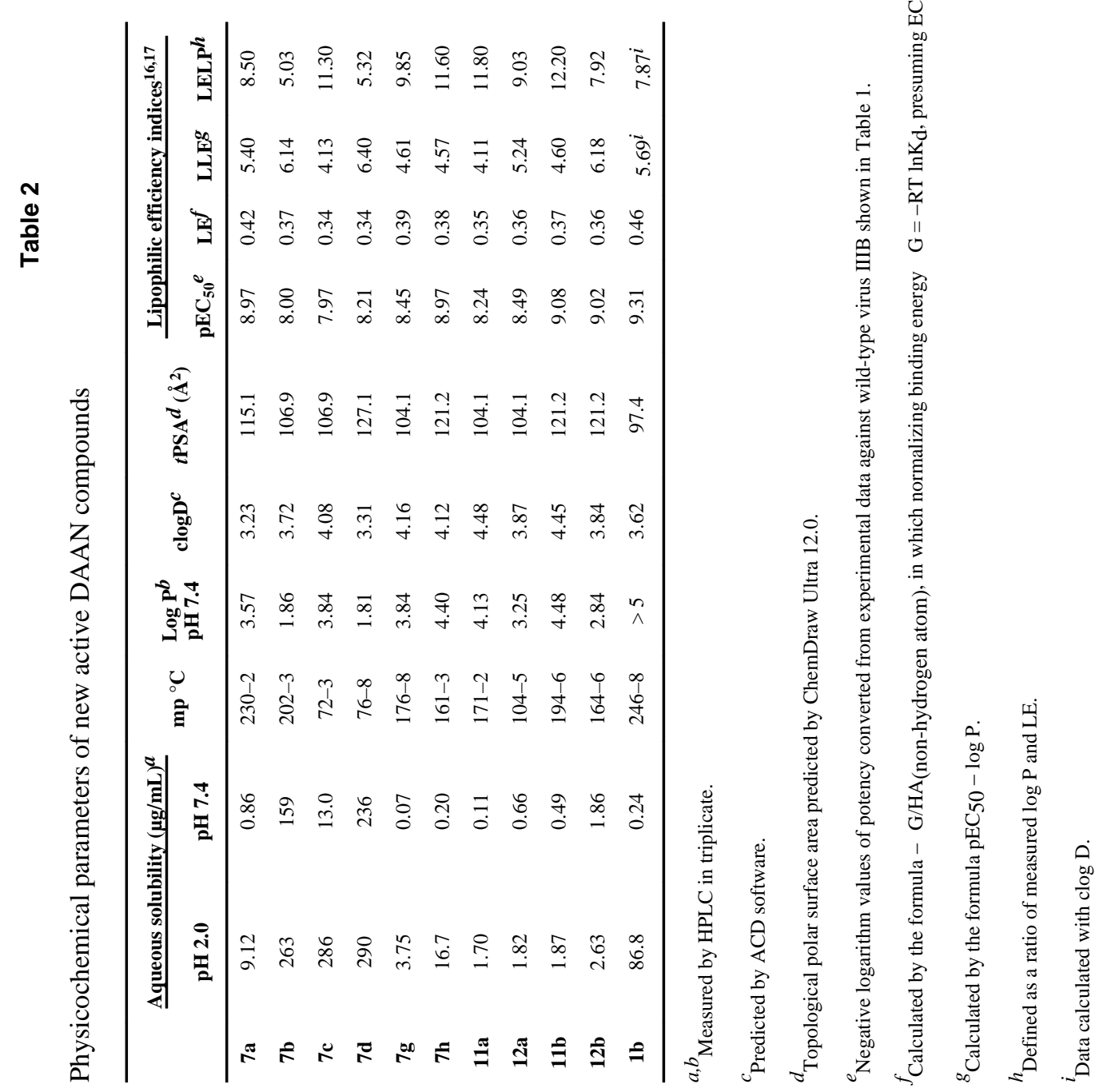

